\title{
CKD-602, a topoisomerase I inhibitor, induces apoptosis and cell-cycle arrest and inhibits invasion in cervical cancer
}

Sungha Lee ${ }^{1}$, Jung Yoon $\mathrm{Ho}^{2,3}$, Jing Jing Liü ${ }^{2,3}$, Hyewon Lee ${ }^{4}$, Jae Young Park ${ }^{2}$, Minwha Baik², Minji Ko², Seon Ui Lee ${ }^{2}$, Youn Jin $\mathrm{Choi}^{2,3^{*+}}$ (D) and Soo Young Hur ${ }^{2,3^{*}+}$

\begin{abstract}
Background: Cervical cancer is the third most common gynecological malignancy. Conventional treatment options are known to be ineffective for the majority of patients with advanced or recurrent cervical cancer. Therefore, novel therapeutic agents for cervical cancer are necessary. In this study, the effects of CKD-602 in cervical cancer were investigated.

Methods: Three established human, immortalized, cervical cancer cell lines (CaSki, HeLa and SiHa) were used in this study. Following treatment with CKD-602, apoptosis was quantified using fluorescein isothiocyanate Annexin V-FITC and propidium iodide (PI) detection kit and cell cycle analysis was analyzed using fluorescence activated cell sorting (FACS). Transwell chambers were used for invasion assays. Western blot assay was performed to analyze proteomics. CaSki cells were subcutaneously injected into BALB/c-nude mice and cervical cancer xenograft model was established to elucidate the antitumor effect of CKD-602 in vivo.

Results: Treatment with CKD-602 induced apoptosis and increased expression of the enzyme PARP, cleaved PARP, and BAX. In addition, expression of phosphorylated p53 increased. Cell cycle arrest at G2/M phase and inhibition of invasion were detected after treatment with CKD-602. A significant decrease in cervical cancer tumor volume was observed in this in vivo model, following treatment with CKD-602.

Conclusions: This is the first report of CKD-602 having an antitumor effect in cervical cancer in both an in vitro and in vivo models. The results of this study indicate that CKD-602 may be a novel potential drug, targeting cervical cancer, providing new opportunities in the development of new therapeutic strategies.
\end{abstract}

Keywords: CKD-602, Cell cycle arrest, Cervical cancer, Topoisomerase inhibitor, Invasion assay

\section{Background}

Cervical cancer is the third most common gynecological malignancy and is responsible for $10-15 \%$ of cancer-related death in women (Jemal et al., 2011). Conventional treatment options (e.g., chemotherapy, radiation and surgical resection) are known to be ineffective for the majority of patients with advanced or recurrent cervical cancer, highlighting the need to identify novel treatment agents (Smith et al., 1993). Only modest

\footnotetext{
*Correspondence: yunno@catholic.ac.kr; hursy@catholic.ac.kr

${ }^{\dagger}$ Youn Jin Choi and Soo Young Hur contributed equally to this work.

2Department of Obstetrics and gynecology, Seoul St. Mary's Hospital, College

of Medicine, The Catholic University of Korea, 222, Banpo-daero,

Seocho-guSeoul 06591 Seoul, Republic of Korea

Full list of author information is available at the end of the article
}

response rates with excessive toxicity were reported without an improvement in survival rate (Chambers et al., 1994). Therefore, novel therapeutic agents for cervical cancer are necessary.

Type I and type II topoisomerase inhibitors interfere with DNA 'unwinding' during DNA replication and RNA transcription. Topoisomerase I (TOP1) cuts one strand in the double-stranded DNA, independent of ATP. In contrast, topoisomerase II (TOP2) cuts both strands in DNA and is dependent on ATP for its activity (Xu and Her, 2015). Camptothecin (CPT) is the TOP1 inhibitor which was originally isolated from the Chinese tree Camptotheca acuminate, however it is no longer in use due to detrimental side

(c) The Author(s). 2019 Open Access This article is distributed under the terms of the Creative Commons Attribution 4.0 International License (http://creativecommons.org/licenses/by/4.0/), which permits unrestricted use, distribution, and 
effects It was replaced by more effective and safer TOP1 inhibitors such as topotecan and irinotecan (Wall and Wani, 1995).

The synthetic water-solube camptothecin analogue, CKD-602, 7-[2-(N-isopropylamino) ethyl]-(20S)-camptothecin (belotecan, Chong Kun Dang Pharmaceutical Corporation, Seoul, Korea), has been shown to be effective in the treatment of various cancers (e.g. glioblastoma, colon and ovarian cancer). The antitumor activity of CKD-602 in cervical cancer has not yet been fully investigated (Lee et al., 1998). In this study, the effects of CKD-602 in cervical cancer cell lines both in vitro and in vivo were investigated.

\section{Materials and methods}

\section{Cell lines and reagents}

Three established human, immortalized, cervical cancer cell lines (CaSki, HeLa and $\mathrm{SiHa}$ ) were used in this study. All three cell lines were integrated with high-risk Human papillomavirus (HPV); CaSki and Siha cell lines were integrated with HPV-16 and the HeLa cell line was integrated with HPV-18. All cell lines were maintained in Roswell Park Memorial Institute (RPMI) 1640, Eagle's Minimum Essential Medium (MEM) and Dulbecco's modified Eagle's medium (DMEM) (Gibco/ThermoFisher Scientific, Waltham, MA, USA) supplemented with $10 \%$ fetal bovine serum (FBS, Gibco) and $1 \%$ penicillin and streptomycin (Gibco) at $37^{\circ} \mathrm{C}$ in a $5 \% \mathrm{CO}_{2}$ incubator. The CKD-602 was dissolved in distilled water with $50 \mathrm{mg}$ D-mannitol (Sigma-Aldrich, St Louis, MO, USA), $0.06 \mathrm{mg}$ at $5 \mathrm{mg} / 1 \mathrm{ml}$ tartaric acid (Sigma-Aldrich), and stored as stock in aliquots at $4{ }^{\circ} \mathrm{C}$. For in vitro use, final concentrations between 15 and $150 \mathrm{ng} /$ ml CKD-602 were obtained by appropriate dilutions of the stock solution in each cell medium. For in vivo use, final concentrations of $25 \mathrm{mg} / \mathrm{kg}$ CKD-602 were obtained by appropriate dilutions of the stock solution with RPMI 1640 medium (Gibco). The CKD-602 was donated from Chong Kun Dang Pharmaceutical Corporation (Seoul, Korea).

\section{Apoptosis assay}

Apoptosis was quantified using the fluorescein isothiocyanate annexin V-FITC and propidium iodide (PI) Apoptosis Detection Kit I (BD Pharmingen, La Jolla, CA, USA) according to the manufacturer's instructions. Briefly, CKD-602-treated and non-treated $1 \times 10^{6}$ cells were washed in ice-cold phosphate buffered saline (PBS), resuspended in $100 \mu \mathrm{L}$ of binding buffer, and incubated with $5 \mu \mathrm{L}$ of annexin V-FITC and $5 \mu \mathrm{L}$ of $\mathrm{PI}$ for $15 \mathrm{~min}$ in a dark room, at room temperature, as per manufacturer's guidelines. Flow cytometric analysis was immediately performed using a FACS Calibur flow cytometer (FACS Calibur; Becton Dickinson, Franklin Lakes, NJ, USA).

\section{Cell-cycle analysis}

The cells at a density of $2 \times 10^{5}$ cells/well in MEM/ DMEM with $10 \%$ FBS were added to the wells of a 6-well plate and incubated overnight. Each cell was treated with 1/2 IC50 and IC50 CKD-602 for $48 \mathrm{~h}$. Following treatment, cells were harvested by centrifugation at $1300 \mathrm{rpm}$ for $3 \mathrm{~min}$, washed twice in ice-cold PBS and fixed by incubating the cells overnight at $-20^{\circ} \mathrm{C}$ with $70 \%$ ethanol. Cells were then washed with ice-cold PBS and resuspended in $500 \mu \mathrm{l} \mathrm{PI} / \mathrm{RNase}$ staining solution (Invitrogen/ThermoFisher Scientific, Waltham, MA, USA). The cell cycle position was evaluated by FACS using an excitation laser set at $480 \mathrm{~nm}$ and a detection wavelength of $575 \mathrm{~nm}$. A minimum of 10,000 30,000 events/sample was analyzed.

\section{Cell invasion assay}

A cell invasion assay was performed to elucidate whether CKD-602 is capable of inhibiting cervical cancer cell invasion (in CaSki, Hela and Siha cell lines). Transwell chambers were used (Corning INc., Corning, NY, USA) and 100 ul cells $(1-2 \times 105$ per well) added to the upper chamber of 24-well plates, which was pre-coated with $30 \mu \mathrm{l}$ of Matrigel (R\&D Systems. catalog no. 1918-FN) for $2 \mathrm{~h}$ under a cell incubator. Concurrently, CKD-602 was diluted with $0.65 \mathrm{ml}$ 20\% FBS-DMEM complete medium(final concentration for CaSki, HeLa and Siha were: $120 \mathrm{ng} / \mathrm{ml}$; $300 \mathrm{ng} / \mathrm{ml}$ and $300 \mathrm{ng} / \mathrm{ml}$, respectively)was added to the lower chamber. After $48 \mathrm{~h}$, the invaded cells in the lower chamber were fixed, stained with $0.1 \%$ crystal violet solution and then photographed under inverted microscope $(\times 200)$.

\section{Western blot analysis}

Briefly, CKD-602-treated and non-treated cells were washed twice in PBS and cell lysates prepared using the radioimmunoprecipitation assay (RIPA). For immnunoblotting, $30 \mu \mathrm{g}$ protein was resolved on $4-12 \%$ SDS-PAGE, transferred onto PVDF membrane (Bio-Rad, Hercules, CA, USA) by electroblotting, and blocked in $5 \%$ BSA in TBST. Membranes were then probed overnight at $4{ }^{\circ} \mathrm{C}$ with the following antibodies: Cyclin B1 (4138); cdc2 (9116); phopho-cdc2 (Tyr15; 9111); p21 (Waf1/ Cip1;2947); p53 (2527); phopho-p53 (Ser15;9286), and PARP (9542) (1:1000; Cell Signaling Technology, Inc. (Danvers, MA, USA). Antibodies to c-PARP (ab32064; 1:1000), phopho-Cyclin B1 (S126; ab133439; 1:10,000), BCL2-associated X protein (Bax, ab32503; 1:2000), matrix mettloproteinases 2 (MMP2, ab97779; 1:5000), and vascular endothelial growth factor (VEGF, ab52917; 1:5000) and 
Cyclin A1 (sc56301; 1:1000) were acquired from Abcam (Cambridge, UK). The antibodies for CDK2 (sc6248; 1:5000) and the housekeeping gene, glyceraldehyde 3-phosphate dehydrogenase (GAPDH, sc32232, 1:5000) were acquired from Santa Cruz Biotechnology (Dallas, TX, USA).

The cell membrane was washed with phosphate buffered saline with Tween 20 (PBST) and incubated with corresponding secondary antibodies for $1 \mathrm{~h}$ at room temperature. Membranes were washed again with PBST and blots were developed into X-Ray films using the enhanced chemiluminescence (ECL) method previously described, or the Chemidoc MP system, Bio-Rad.

\section{Xenograft model}

All animal experimental protocols were reviewed and approved by the Catholic University Animal Care and Use Committee and performed in accordance with the National Institute of Health Guide for the Care and Use of Experimental Animals. Normal six-week-old female BALB/c-nude mice (17-22 g) were purchased from Orient Bio (Gyeonggi-do, Korea). Specifically, CaSki cells $\left(4 \times 10^{6} /\right.$ head $)$ were subcutaneously injected into the right leg of the mouse. After two weeks, when the tumor had attained an average volume of approximately $80 \mathrm{~mm}^{3}$, tumor sizes were measured using a vernier caliper weekly and tumor volume calculated [(tumor length) $\times$ (tumor width) ${ }^{2} / 2$ ]. The dose of CKD-602 (25 $\mathrm{mg} / \mathrm{kg}$ ) was chosen based upon previous reports (Kim et al., 2013). The CKD-602 was injected intravenously for 16 days at 4-day intervals and PBS as a negative control was injected in same way. After CKD-602 treatment, tumor volumes and body weights were measured every 3-4 days from day 17 . Mice were killed 4 weeks after establishment of the xenograft.

\section{Statistical analysis}

All statistical analyses were performed using one-way ANOVA comparing variable groups (Graphpad Prism5 software). All experiments were repeated at least three times. In certain cases, the Student's t-test was also performed. Values are expressed as mean \pm standard error of the mean (SEM) for control and treated samples. A $p$ value of $<0.05$ was considered statistically significant $(" p<<0.05$, ${ }^{* * *} p<0.01,{ }^{* * * * *} p<0.001, \mathrm{~ns}=$ not significant).

\section{Results}

CKD-602 promotes pro-apoptotic activity in cervical cancer

Using the cell viability assay, treatment with CKD-602 showed a significant cytotoxic effect in all cervical cancer cell lines in a time- $(p<0.05)$ and dose- $(p<0.05)$

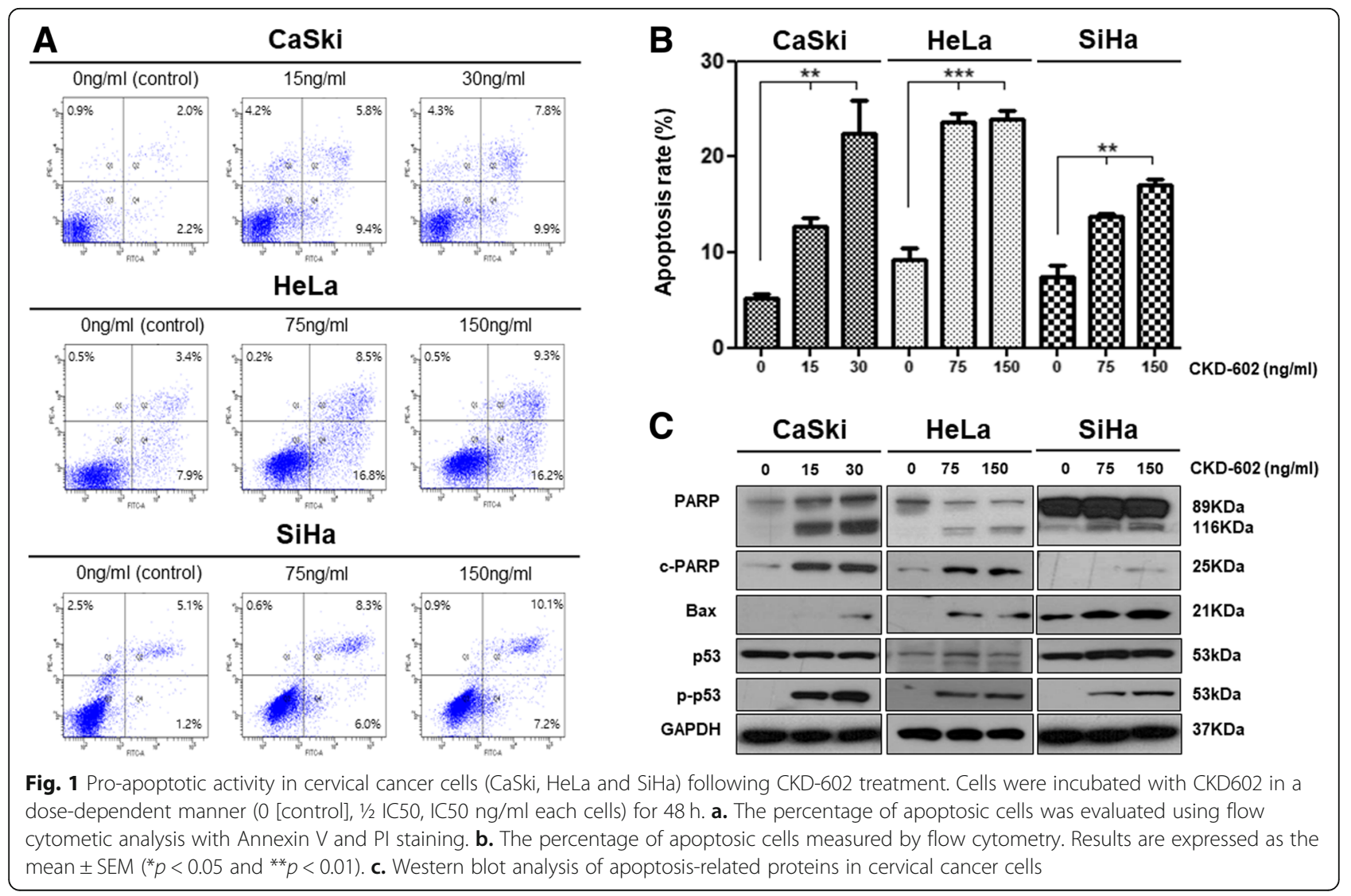


dependent manner (Additional file 1: Figure S1). The IC50 (50\% inhibition concentration of cell viability) values were $30 \mathrm{ng} / \mathrm{ml}$ (95\% CI: 18.29-63.30) for Caski cells, $150 \mathrm{ng} / \mathrm{ml}$ (95\% CI: 100.3-179.4) for HeLa cells, and $150 \mathrm{ng} / \mathrm{ml}$ (95\% CI: 64.63-254.3) for SiHa cells at $48 \mathrm{~h}$ after treatment. To investigate the efficacy of CKD-602 in cervical cancer, pro-apoptotic activity was measured. A strong pro-apoptotic activity was observed in the treatment groups after $48 \mathrm{~h}$ of treatment (Fig. 1a and b). Compared to the control, apoptosis rates significantly increased in Caski, HeLa and Siha when treated with different concentrations (half the IC50 and IC50 values). The treatment increased the expression of PARP, cleaved PARP and $\mathrm{Bcl} 2$-associated $\mathrm{X}$ protein (BAX). In addition, expression of both p53 and phosphorylated p53 (Ser15) was increased (Fig. 1c).

\section{CKD-602 induces cell-cycle arrest in the G2/M phase in cervical cancer}

Cell cycle analysis was performed following CKD-602 treatment with different concentrations (half the IC50 and IC50 values) after $48 \mathrm{~h}$ of treatment (Fig. 2). Treatment induced the G2/M phase cell accumulation in all cell lines in a concentration-dependent manner. The proportion of the cell population in $\mathrm{G} 2 / \mathrm{M}$ phase at $48 \mathrm{~h}$ increased from 26.3 to $64.5 \%$ (CaSki cells), 23.4 to $70.9 \%$ (HeLa cells) and 16.0 to $61.0 \%$ ( $\mathrm{SiHa}$ cells). This increase was statistically significant $(" p<0.05$ and $* * 0<01)$. We investigated the $\mathrm{G} 2 / \mathrm{M}$ - related protein levels. The increases in cyclin B1 and phosphorylated cyclin B1 (phosphor Ser126) expression levels were present in all the cell lines. Expression of Cdc2 protein did not show substantial change but phospho-cdc2 (Tyr15) protein expression increased after CKD-602 treatment.

\section{CKD-602 inhibits cancer invasion in cervical cancer}

$\mathrm{An}$ in vitro invasion assay was performed to investigate whether CKD-602 treatment affected the invasive ability of cervical cancer cells. The assay was performed in chambers that had the upper wells coated with Matrigel to mimic the extracellular matrix in vivo. All the cervical cancer cell lines were treated with IC50 concentrations and representative photomicrographs of the membrane-associated cells $(\times 200)$ taken and analyzed (Fig. 3a). Significant differences of invasive ability were detected between the control cells and the CKD-602 treated cells (Fig. 3b) (" $p<0.05$ and $\left.{ }^{* *} p<0.01\right)$. The protein expression levels of MMP2 and VEGF, two

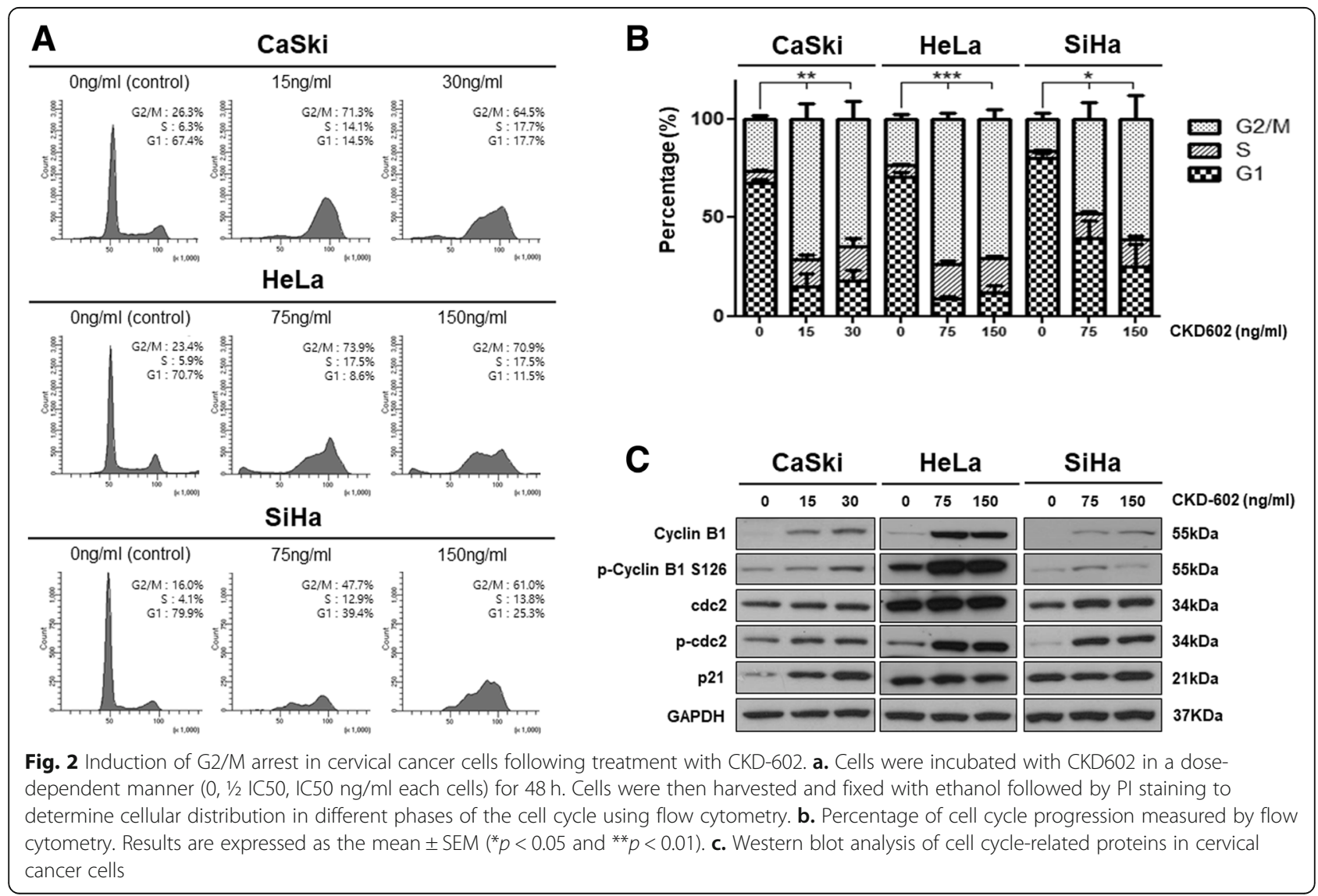




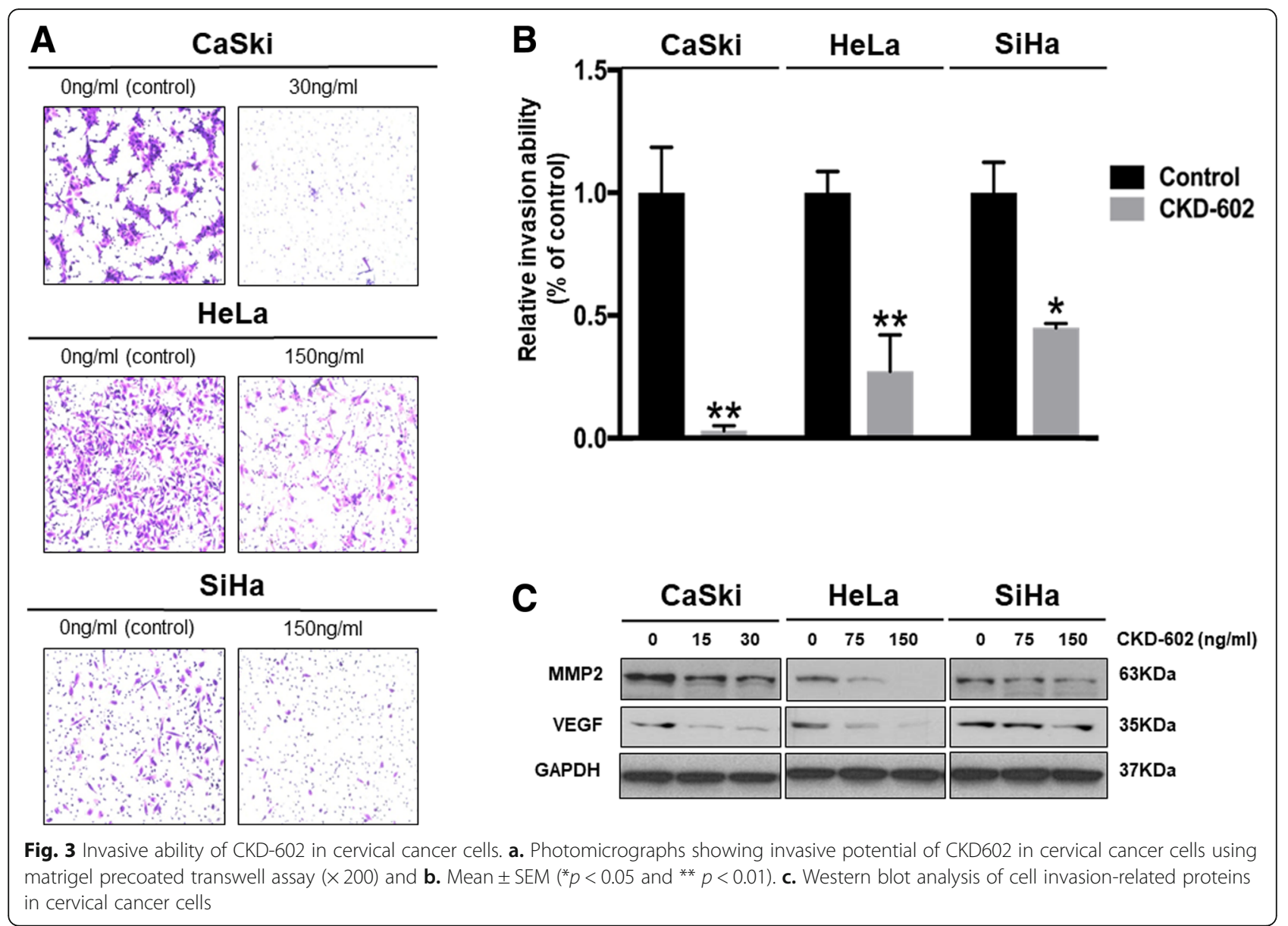

proteins known to be specifically related to the invasive ability of cells, decreased following CKD-602 treatment (Fig. 3c).

\section{Inhibition of tumor growth in CaSki-xenografted nude mice}

Based on the in vitro data, it was then investigated whether CKD-602 would also be effective in an in vivo model. Groups of BALB/c-nude mice (five per group) were subcutaneously injected with CaSki cells and then treated (intravenously) with CKD-602 (25 m/ $\mathrm{kg}$ ) or PBS two weeks after the transplantation, when the tumors were approximately $80 \mathrm{~mm}^{3}$ (Fig. 4a). Seventeen days after the last injections, the mice were killed and the tumor volume measured and body weights of the mice recorded (Fig. 4b). Treatment with CKD-602 significantly inhibited the tumor growth of in this xenograft model compared with the control $(p<0.05)$. There was no significant difference in bodyweight between the xenograft mice and the controls, indicating that treatment with CKD-602 was well tolerated (Fig. 4b).

\section{Discussion}

Topoisomerase I (TOP1) inhibitors (e.g. toptecan and iritonecan) are currently used in the treatment of cervical cancer treatment (https://www.nccn.org). Previous studies have demonstrated that CKD-602, a TOP1 inhibitor, is effective in the treatment of various cancers such as small cell lung carcinoma, oral squamous cell carcinoma and glioblastoma (Kim et al., 2013; Kim et al., 2015; Lee et al., 1998). In the current study, treatment with CKD-602 as a potential anticancer drug targeting cervical cancer was investigated for the first time. In both in vitro and in vivo models, treatment with CKD-602 promoted apoptosis, induced cell cycle arrest in G2/M phase and inhibited cancer invasion.

Based upon previous reports indicating that CKD-602 has anticancer effects (Kim et al., 2013; Lee et al., 1998) a possible pro-apoptotic effect in cervical cancer was investigated. Using three distinct human cervical cancer cell lines (CaSki [HPV - 16], HeLa [HPV-18], and $\mathrm{SiHa}$ [HPV-16]), it was demonstrated that activation of BAX and PARP cleavage were enhanced $48 \mathrm{~h}$ after treatment (Fig. 1). In addition, 


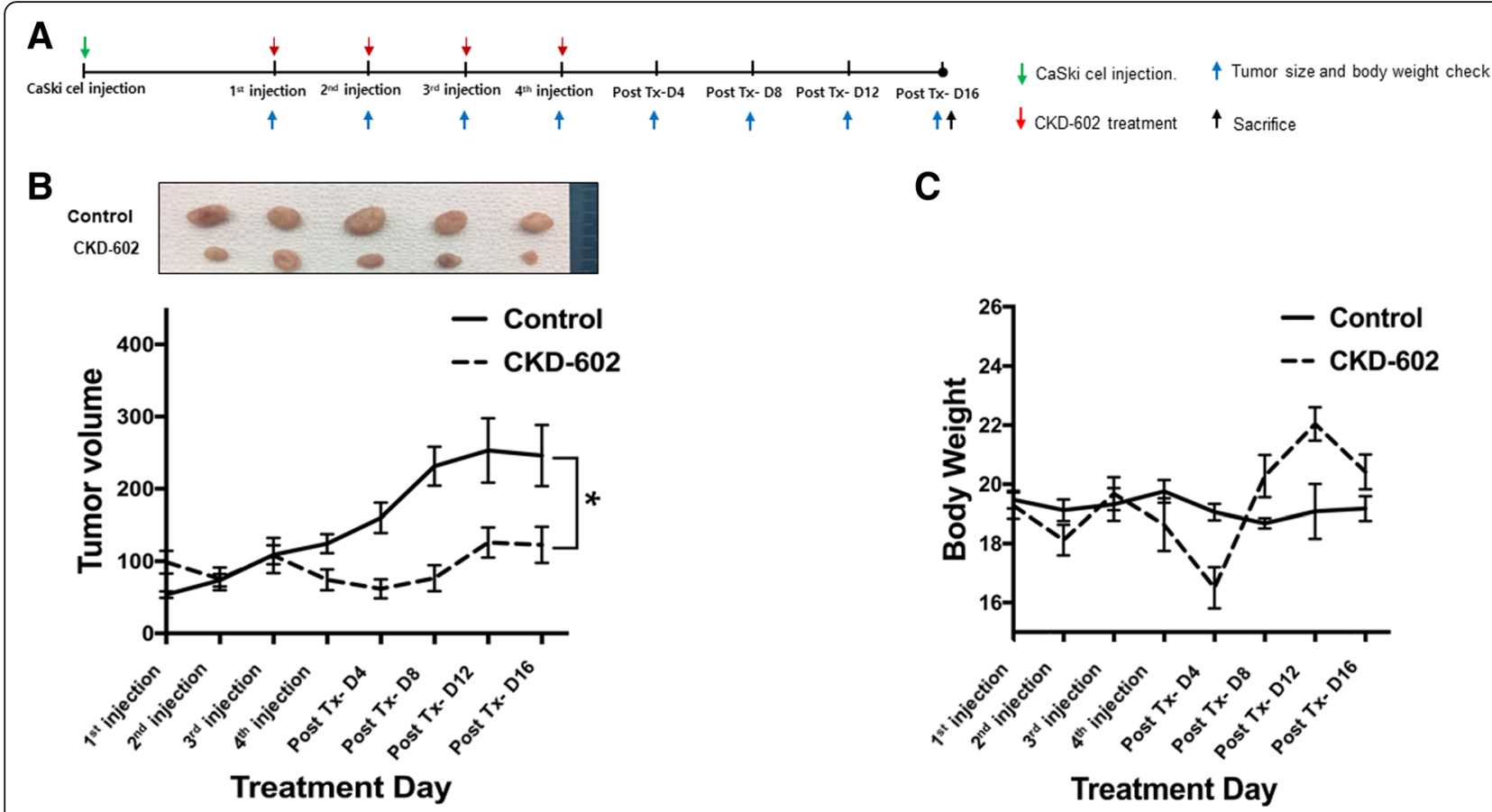

Fig. 4 Antitumor efficacy of CKD-602 in a CaSKi xenograft model. a. Schematic diagram of the treatment regimen of CKD-602. Groups of BALB/Cnude mice (five per group) were subcutaneously challenged with CaSki $4 \times 10^{6}$ CaSki tumor cells per mouse. b. Tumor volume in CaSki tumorbearing mice in control mice and the CKD-602-treated mice. Results are expressed as mean \pm SEM $\left({ }^{*} p<0.05\right)$. c. Body weight of CaSki tumorbearing mice in control mice and CKD-602-treated mice

phosphorylation of p53 occurred after treatment. Previous studies have reported that phosphorylation of p53 modulates the functions of p53 and is causally related to apoptosis (Milne et al., 1995; Zhang et al., 1994). Furthermore, it has been demonstrated that p53 can activate the expression of BAX, a member of the Bcl-2 family, and that BAX can act to accelerate apoptosis (Basu and Haldar, 1998; Haupt et al., 2003; Miyashita et al., 1994). Pro-apoptotic signaling induced by TOP1 inhibitors has been reported in previous studies, suggesting that TOP1 possesses a protein-kinase activity that is specific to serine residues (García et al., 2014; Gobert et al., 1999; Tazi et al., 1997). Together, the data from the current study indicates that treatment with CKD-602 may induce apoptosis through phosphorylation of p53 in cervical cancer.

The effect of CKD-602 treatment in cell-cycle arrest in cervical cancer was investigated. It was found that treatment with CKD-602 is capable of inducing G2/M phase cell-cycle arrest in cervical cancer. Cell-cycle arrest at the G2/M phase is associated with enhanced apoptosis and is a cellular response to various DNA-damaging agents (DiPaola, 2002). A previous study has demonstrated CKD-602-induced cell-cycle arrest at the G2/M phase in oral squamous cell carcinoma cancer and the data from the current study indicates that the same may be true in cervical cancer (Kim et al., 2015). As shown in Fig. 2, expression of cyclin B1, phosphorylated cyclin B1 and p21 increased in cervical cancer following CKD-602 treatment. It is well known that p53 regulates the $\mathrm{G} 2 / \mathrm{M}$ checkpoint through cyclin B1 (Innocente et al., 1999) however it has also been reported that some TOP1 inhibitors can induce p53-independent $\mathrm{G} 2 / \mathrm{M}$ arrest (Bozko et al., 2002; Wu et al., 2015). Further studies are required to determine if G2/M arrest after CKD-602 treatment is p53-dependent or independent.

Several TOP1inhibitors have been reported to be involved in the inhibition of cancer invasion (Elstner et al., 2007; Min et al., 2011). The results of the current study are the first to show that inhibition of cancer invasion by CKD-602, a TOP1 inhibitor. It was found that expression of MMP2 and VEGF decreased $48 \mathrm{~h}$ after CKD-602 treatment in 3 cervical cancer cell lines (CaSki, HeLa and $\mathrm{SiHa}$ ). Matrix metalloproteinases (MMPs), a family of enzymes, proteolytically degrade various components of the extracellular matrix (ECM). Increased expression of MMPs is associated with the increase of tumor cells in an organ (Zhang et al., 2015).Vascular epithelial growth factor (VEGF) is a mitogen that induces a rapid and complete angiogenic response to cancersous/tumor cells in an organ 
(Carmeliet, 2005). In addition, a previous study has shown that cell invasion is promoted via VEGF and MMP2 in cervical cancer (Chen et al., 2014).

\section{Conclusions}

This is the first study to identify and report the anticancer effects of CKD-602 treatment in cervical cancer, in both in vitro and in vivo models. The data suggests that p53-mediated apoptosis, cell cycle arrest at G2/ M phase and inhibition of invasion through MMP2 and VEGF were involved in these processes. CKD-602 may be a potential drug targeting cervical cancer that will lead to new opportunities to develop new therapeutic strategies.

\section{Additional file}

Additional file 1: Figure S1. Cell viability following CKD-602 treatment. (TIF $130 \mathrm{~kb})$

\section{Abbreviations}

BAX: Bcl2-associated X protein; CPT: camptothecin; FACS: fluorescence activated cell sorting; MEM: Minimum Essential Medium; PI: propidium iodide; RPMI: Roswell Park Memorial Institute; TOP1: topoisomerase I;

TOP2: topoisomerase I

\section{Acknowledgements}

We acknowledge the support of Chong Kun Dang Corporation for the donation of CKD-602 supplements for the study.

\section{Funding}

This work was supported by Chong Kun Dang Corporation and Bio \& Medical Technology Development Program of the National Research Foundation (NRF) funded by the Ministry of Science \& ICT (2018M3A9E8021512).

\section{Availability of data and materials}

Data sharing not applicable to this article as no datasets were generated or analyzed during the current study.

\section{Author's contributions}

Sungha Lee and Youn Jin Choi wrote the manuscript. Youn Jin Choi and Soo Young Hur designed the study. Jung Yoon Ho, Jing Jing Liu and Hyewon Lee did animal experiments and analyzed the data. Jae Young Park, Minwha Baik, Minji Ko, Seon Ui Lee and Jung Yoon Ho performed the in vitro analysis and interpreted the data. All authors read and approved the final manuscript.

\section{Ethics approval and consent to participate}

All animal experimental protocols were reviewed and approved by the Catholic University Animal Care and Use Committee and performed in accordance with the National Institute of Health Guide for the Care and Use of Experimental Animals.

\section{Consent for publication}

There is no contains about any individual person's data in any form and there is no need to get consent for publication.

\section{Competing interests}

The authors declare that they have no competing interests.

\section{Publisher's Note}

Springer Nature remains neutral with regard to jurisdictional claims in published maps and institutional affiliations.

\section{Author details}

'Departments of Obstetrics and gynecology, Gangseo MizMedi, Ganseogu Gangseoro 295, Seoul 07639, Republic of Korea. ${ }^{2}$ Department of Obstetrics and gynecology, Seoul St. Mary's Hospital, College of Medicine, The Catholic University of Korea, 222, Banpo-daero, Seocho-guSeoul 06591 Seoul, Republic of Korea. ${ }^{3}$ Cancer Research Institute, College of Medicine, The Catholic University of Korea, 222, Banpo-daero, Seocho-guSeoul 06591 Seoul, Republic of Korea. ${ }^{4}$ Department of Health Sciences and Technology, SAIHST, Sungkyunkwan University, Gangnam gu Ilwonro 81, Seoul 06351, Republic of Korea.

Received: 5 March 2019 Accepted: 6 May 2019

Published online: 28 May 2019

\section{References}

Basu A, Haldar S. The relationship between Bc12, Bax and p53: consequences for cell cycle progression and cell death. Mol Hum Reprod. 1998;4:1099-109.

Bozko P, Larsen AK, Raymond E, Skladanowski A. Influence of G2 arrest on the cytotoxicity of DNA topoisomerase inhibitors toward human carcinoma cells with different p53 status. Acta Biochim Pol. 2002;49:109-19.

Carmeliet P. VEGF as a key mediator of angiogenesis in cancer. Oncology. 2005 69(Suppl 3):4-10

Chambers SK, Lamb L, Kohorn El, Schwartz PE, Chambers JT. Chemotherapy of recurrent/advanced cervical cancer: results of the Yale University PBM-PFU protocol. Gynecol Oncol. 1994;53:161-9.

Chen B, Zhang C, Dong P, Guo Y, Mu N. Molecular regulation of cervical cancer growth and invasion by VEGFa. Tumour Biol. 2014;35:11587-93.

DiPaola RS. To arrest or not to G(2)-M cell-cycle arrest : commentary re: A. K. Tyagi et al., Silibinin strongly synergizes human prostate carcinoma DU145 cells to doxorubicin-induced growth inhibition, G(2)-M arrest, and apoptosis. Clin cancer res. 8: 3512-3519, 2002. Clin Cancer Res. 2002;8:3311-4.

Elstner A, Holtkamp N, von Deimling A. Involvement of Hif-1 in desferrioxamineinduced invasion of glioblastoma cells. Clin Exp Metastasis. 2007;24:57-66.

García CP, Videla Richardson GA, Romorini L, Miriuka SG, Sevlever GE, Scassa ME. Topoisomerase I inhibitor, camptothecin, induces apoptogenic signaling in human embryonic stem cells. Stem Cell Res. 2014;12:400-14.

Gobert C, Skladanowski A, Larsen AK. The interaction between p53 and DNA topoisomerase I is regulated differently in cells with wild-type and mutant p53. Natl Acad Sci U. S. A. 1999:96:10355-60.

Haupt S, Berger M, Goldberg Z, Haupt Y. Apoptosis - the p53 network. J Cell Sci. 2003;116:4077-85.

Innocente SA, Abrahamson JL, Cogswell JP, Lee JM. p53 regulates a G2 checkpoint through cyclin B1. Natl Acad Sci U S A. 1999;96:2147-52.

Jemal A, Bray F, Center MM, Ferlay J, Ward E, Forman D. Global cancer statistics. CA Cancer J Clin. 2011;61:69-90.

Kim YH, Lee JK, Kim B, DeWitt JP, Lee JE, Han JH, Kim SK, Oh CW, Kim CY. Combination therapy of cilengitide with belotecan against experimental glioblastoma. Int J Cancer. 2013;133:749-56.

Kim YK, Koo NY, Yun PY. Anticancer effects of CKD-602 (Camtobellø) via G2/M phase arrest in oral squamous cell carcinoma cell line. Oncol Lett. 2015;9: $136-42$.

Lee JH, Lee JM, Kim JK, Ahn SK, Lee SJ, Kim MY, Jew SS, Park JG, Hong Cl. Antitumor activity of 7-[2-(N-isopropylamino)ethyl]-(20S)-camptothecin, CKD602, as a potent DNA topoisomerase I inhibitor. Arch Pharm Res. 1998: 21:581-90.

Milne DM, Campbell LE, Campbell DG, Meek DW. p53 is phosphorylated in vitro and in vivo by an ultraviolet radiation-induced protein kinase characteristic of the c-Jun kinase, JNK1. J Biol Chem. 1995;70:5511-8.

Min R, Zun Z, Min Y, Wenhu D, Wenjun Y, Chenping Z. Shikonin inhibits tumor invasion via down-regulation of NF-KB-mediated MMP-9 expression in human ACC-M cells. Oral Dis. 2011;17:362-9.

Miyashita T, Harigai M, Hanada M, Reed JC. Identification of a p53-dependent negative response element in the bcl-2 gene. Cancer Res. 1994;54:3131-5.

Smith HO, Stringer CA, Kavanagh JJ, Gershenson DM, Edwards CL, Wharton JT. Treatment of advanced or recurrent squamous cell carcinoma of the uterine cervix with mitomycin-C, bleomycin, and cisplatin chemotherapy. Gynecol Oncol. 1993:48:11-5.

Tazi J, Rossi F, Labourier E, Gallouzi I, Brunel C, Antoine E. DNA topoisomerase I: customs officer at the border between DNA and RNA worlds? Journal of molecular medicine (Ber). 1997;75:786-800. 
Wall ME, Wani MC. Camptothecin and taxol: discovery to clinic--thirteenth Bruce F. Cain memorial award lecture. Cancer Res. 1995:55; 753-60.

Wu CC, Huang KF, Yang TY, Li YL, Wen CL, Hsu SL, Chen TH. The topoisomerase 1 inhibitor Austrobailignan-1 isolated from Koelreuteria henryi induces a G2/ M-phase arrest and cell death independently of p53 in non-small cell lung Cancer cells. PLoS One. 2015;10:e0132052.

Xu Y, Her C. Inhibition of topoisomerase (DNA) I (TOP1): DNA damage repair and anticancer therapy. Biomolecules. 2015;5:1652-70.

Zhang L, Zhou Y, Cheng C, Cui H, Cheng L, Kong P, et al. Genomic analyses reveal mutational signatures and frequently altered genes in esophageal squamous cell carcinoma. Am J Hum Genet. 2015;96:597-611.

Zhang W, McClain C, Gau JP, Guo XY, Deisseroth AB. Hyperphosphorylation of p53 induced by okadaic acid attenuates its transcriptional activation function. Cancer Res. 1994;54:4448-53.

Ready to submit your research? Choose BMC and benefit from:

- fast, convenient online submission

- thorough peer review by experienced researchers in your field

- rapid publication on acceptance

- support for research data, including large and complex data types

- gold Open Access which fosters wider collaboration and increased citations

- maximum visibility for your research: over $100 \mathrm{M}$ website views per year

At BMC, research is always in progress.

Learn more biomedcentral.com/submissions 